\title{
The Effect of Board of Directors and Audit Committee Characteristics on Company Performance in Jordan
}

\author{
Ala Hussein Albawwat ${ }^{1}$, Ammar Almansour ${ }^{1}$, Mo'taz Kamel Al Zobi ${ }^{1}$ \& Nahed Habis Alrawashedh ${ }^{1}$ \\ ${ }^{1}$ Faculty of Business, Amman Arab University, Amman, Jordan \\ Correspondence: Ala Hussein Albawwat, Faculty of Business, Amman Arab University (AAU), Amman 11953, \\ Jordan.
}

Received: August 3, 2020

Accepted: October 13, 2020

Online Published: November 30, 2020

doi:10.5430/ijfr.v11n6p10

URL: https://doi.org/10.5430/ijfr.v11n6p10

\begin{abstract}
A comparative study was conducted to evaluate the effects of audit committee and directorates on the performance characteristics of selected companies in Jordan. The approach of panel data was adopted between 2015 to 2019 (4 years), with listed samples of 140 non-financial industries under the ASE. These firms stand for about $60 \%$ of listed firms in Jordan. Considering the audit committee and directorates effects of board characteristics on company's performance, a total number of seven (7) variables of directorates and that of auditing committee were identified: an independent board of director, meetings of the board, size of the board, structure of the leadership, size of auditing committee, independent auditing committee together with proficiency of audit committee. The performance characteristics of companies were evaluated by means of (ROA) measure of accounting based performance. It was indicated from the results that, the following variables (independent board of directors, expert in auditing committee positively had impact on the performance ability of the selected firms. It was also revealed that, independent auditing committee together with board size of smaller capacity could enhance the performance potential of the firms. In addition to this, No significant difference was revealed on the performance of firms in term of frequency of board meetings and structure of leadership. The present research however adds more contribution to the literature on how the nature of directorate board and auditing committee could affect performance of a company in Jordan and other developing nations. However, information of great important value could assist academicians, policy makers alongside with concern stakeholders.
\end{abstract}

Keywords: audit committee, board of directorates, company performance, Jordan

\section{Introduction}

The Corporate governance (CG) deals with many settings of governance and it are seen to be an important asset in many area of study. With the aim to maximize the wealth of shareholders, the CG can be used to regulate the corporation as mentioned by Akbar (2015) and Emile et al. (2014). A good CG has the potential to foster cogent information to shareholders of firms, managers plus other beneficiary agencies with the main target of improving the overall performance of the firms (Duztas, 2008). It was also argued that, firms characterised by good CG could perform better compared to firms of low CG Black (Jang and Kim 2006).

The board of directors (BoDs) was known to be among the most important key tools of CG and safeguarding of structural governance between their firms and shareholders (Liu and Fong, 2010; Arora, 2015). From a report revealed by Cadbury in 1992, it has been mentioned that, the BoDs stood out to contribute immensely to the success and progress of their firm. On this note, CG is focused more in the mechanism actions of board of directors BoDs in line with its tasks, structures, activities, relationships and mechanism action (Arora, 2015).

The audit committee (AC) was described to be a relevant board subcommittee for the fact that, it has the ability to protect the shareholder's interest in relation with lapse and control of financial structure (Mallin, 2007). The process of supervising financial reporting of any company happens to be the major duty performed by AC. Aside that, reviewing of financial reports, controlling of internal account, auditing process are as well including among the primary roles of $\mathrm{AC}$ in a given firm (Klein, 2002).

The survival of $\mathrm{AC}$ and BoDs is a critical to note for an effective operation of listed firms and to better improve structural performance of the company. In accordance to the perception of agency theory the AC and BoDs take 
responsibility to undertake various functions and these include: supervision of management behaviours to neutralise the lapses that could arise from any agency and align the safety of management and that of shareholders, ideal supervision of chief executive officer (CEO), firing and appointing staff and subsequently protection of the interest of shareholders (Fama \& Jensen, 1983b McIntyre, Murphy, \& Mitchell, 2007; Amran, et al., 2010; La Porta et al., 1997). In addition to that, the theory of resource dependence mentioned that, the BoDs signified creative and tactical tool in a given company as revealed by Miller \& Triana (2009). As examples, counselling and advising firm's managers, sustaining the public profile of a company firm, , fostering of external dealings, establishment of expertise and the likes (Bathula, 2008). However, the above mentioned functions have to potential to enact positive impact on the overall performance characteristics of any firm by playing an essential duty in the decision-making process of a company (Fama \& Jensen, 1983a).

The impacts of the BoDs on the performance of companies have been revealed by many researchers. It should however be noted that, most of the studies related to this were broadly conducted in advanced nations. In the United Kingdom (UK) and United States of America (USA), the following authors were prominent: Weir et al., 2002; Anderson \& Reeb, 2004;, 2013; El-Faitouri, 2014; Horvath and Spirollari, 2012; Mura, 2006; Bhagat and Bolton, 2008 and Guest, 2009). In developing nations, like Egypt these authors (Wahba \& Zaima, 2015; Desoky \& Mousa, 2012; Emile et al., 2014) worked extensively on BoDs Authors like Shukeri et al. (2012); Amran \& Ayouib (2011); Fooladi \& Shukor (2012) conducted their researches considering Malaysia as case sample. In China the works of Y. Liu et al., (2015); Hu, Tam, \& Tan (2010) were revealed. In Romania (Achim at al., 2016) and in India by Arora and Sharma (2016).

In the world of Middle East, the persistence incidence of revolutions in some of the Arab nations and meltdown of financial structure (with example from the Dubai crisis in 2009 and 2008 global crisis) resulted in renewal of interest to obtain proper knowledge on the function of the BoDs to positively impact the performance of a company. To be specific, a new zeal to study possible relationship related to BoDs in Jordan was carefully analysed and this was mainly due to various reasons. First of all, it should be made known that, the 'Arab Spring' influenced the economy in Jordan and for this fact, and majority of potential investors were forced move out their capitals from Jordan to other promising and reliable nations. This consequently negatively impacted performance of Jordanian's firms as mention by Almasarwah, (2015). Again, it must be recalled that in 2012 Jordan Phosphate Mines Company (JPMC) was involved in a scandal where the office of the board chairman was abused coupled with some areas of board governance that were ignored. For instance, divide roles of CEOs, board chairman, and independent board (Khorma, 2014). However, research in the past with reference to Jordan addressed this relationship and the following authors could ascertain that (Zedan and Abu Nassar, 2014; Alwshah, 2009; Jaafar and El Shawa, 2009). Meanwhile, the work of Marashdeh (2014) has been focused on data prior to the implementation of the Code of Corporate Governance in Jordan (CCGJ) in the year 2009.

As a small developing nation found within heart of Middle East, Jordan differs from many other nations regarding economic aspect, ownership structures and legal framework. As a matter of fact, most owners do prefer to control or manage their firms personally where larger stocks are owned by themselves (Slihat, \& Alnimer, 2013; Warrad, Almahamid,). More so, Jordan was observed to have little sources to depend upon, poor budget allocation, and the nation (Jordan) suffered from the scandals and collapses and the neighbouring nations around Jordan witnessed collapses, unbalanced political climate and civil war.

Upon all economic meltdown and unstable political atmospheric conditions faced by Middle East most especially in Jordan, the economy of Jordan still experienced tangible progress. A number of listed companies under the data base of Amman Stock Exchange (ASE) were significantly improved and the trade volumes keep growing up in recent years. Reasonable amount of improvements has been manifested the government of Jordan to attract foreign investors at all level to grow the economy of Jordan by integrating the global economy; as a case sample, the liberation of capital markets, transparency via proper regulation of policies, disclosure and sound accountability have been introduced to the system and corporate governance structure have been reformed successfully (Idris, 2012; Marashdeh, 2014).

In another way round, the board could stand for a strategic resource in any firm, as the board could better improve through decision making process for the firm to grow. The work of Bathula (2008) testified to there where the board was found to boost the image of certain firms, provision of expertise, improvement of external relations, counselling and proper implementation of administering advice and so on. This finding connote with the model of resource dependence, which propelled that the BoDs must first stand give out various resources to the company as their primary duty. 
It was argued that BoDs in Jordan was characterized by weak disciplinary function of corporate devices simply because of the poor mechanisms action that governed the BoDs composition, poor concepts of awareness of a real independent directors, and weak guiding principles to regulate non-executive and executive directors balance (Alwshah, 2009). More so, Poor awareness on the board governance in Jordan, like the forming of committees provision, independent directors appointment and CEO duality (; Al Ramahi, et al., 2014; Al-Kassar \& Al-Nidawiy, 2014). The work revealed by Matar and Nauimat (2014) mentioned that, in Jordan the mechanism action and implementation of board governance remain poor, and for this reason the potentials of boards for effective monitoring will become poor. This in turn had a negative impact decision making activities general performance of the firms in question (Bathula, 2008; Arora \& Sharma, 2016).

From the discussion above on how critical the BoDs is to the success of any firm, various factors might be involved to properly evaluate the performance of firm in connection with the BoDs in Jordan. Basically, it has become a great concern about the ability of BoDs to positively impact in firm's performance due unsatisfactory level of some shareholders to solve the poor nature and weak performance status of firms in question (Zureigat et al., 2014; Matar \& Nauimat, 2014;). Again, an improved awareness by some of the shareholders on the effectiveness of board to serve as backbone through provision of better shareholder returns, capital investment attraction and overall improvement of firm to perform at their best level (Marashdeh, 2014). In line with such notion, the present research is therefore necessary to evaluate the possible effects of the BoDs on the performance characteristics of some listed firms in Jordan.

\section{Hypotheses Development and Theoretical Background}

It is a fact that, the BoDs supervise the management of the company and ethically and legally in charge of shareholders and still remain as the upper executive unit of a firm. However, the BoDs mainly perform the work of management supervision in care of the shareholders of the company (Arora, 2015). The role performed by AC is as well seen to be relevant to stakeholders as this could further enhance the performance of the market via better disclosure of financial reports. The impacts of the AC has grown up over the years and was re-defined in liberal way from a voluntary monitoring actions been adopted in cost of agency that are high to better develop the qualitative information that could reach the shareholders. Currently it is a key ingredient to consider for the benefits of both private and public firms. Now that, the responsibilities of the AC could be observed to monitor the accounting process and financial reporting and auditing functions to the companies in question (Sarbanes-Oxley Act, 2002).

This implies that, a committed independent couple with a suitable qualified AC could stand to safeguard the interest of the public at large (Abbott et al., 2002). Many researches from various authors have been carried out in the past to evaluate the relationship that could occur among the BoDs and the characteristics of audit committee on the performance of a company. However, the following mechanisms will be addressed in the current study: board of directors' independence, board meetings, board size, leadership structure, audit committee size, audit committee independence and audit committee expertise.

\subsection{Board of Directors Mechanisms}

\subsubsection{Board of Directors' Independence}

According to Silva \& Leal (2005), an independent board is linked to the accessible nature of external directors in the BoDs. This is very important in the reforms of most corporate governance in a developed as well as in an emerging markets, and could successfully perform the work supervision, engage in high level of professional in listed firms. More so the level of misconducts by top executives of the firm could be minimized which subsequently get rid wasteful resources of the company, and thus performance would be improved significantly (Chiang, 2005; Black et al., 2006). From the theory of agency, the manifestation of independent directors could improve the performance of the firm through a service monitoring with no bias, and could lead to proper guidance of both the shareholders and the expertise of the company (Fama \& Jensen, 1983b).

According to Lutfi, Iramani, \& MellyzaSilvy (2014), a board with independent directors have the ability to solve agency problems among owners and managers of the firm with the possibility to achieve a good decision-making process by the executive of the firm. The theory of stewardship in contrary revealed that, firms performing at higher level were associated with internal directors due to the fact that, directors from within possess better knowledge of the business activity been governed more than the external directors with the ability to put decisions of high quality (Albrecht et al., 2004; Aduda et al., 2013). From another point of view by the theory of resource dependence, the independent directorates could improve the usefulness of the members of the board that has been focused more on 
counselling and advise provided to the management together with the available amount of resources of the company and the Chief Executive Offices through the members of the board (Aduda et al., 2013).

The relative effects among company's performance and the amount of external directors (independent board), are complex and studies in this aspect still remain controversial (Brown and Caylor, 2009). Studies conducted by the following authors (Duchin et al., 2010; Coles, Danielb, and Naveen, 2012; Olusola, and Abiodun, 2013) revealed positive relationship between firms performance and the independence of BoDs. Authors from their findings propelled out possible reason for their claims as, independent directors is tantamount to a financial independent of management system, protection over the shareholder's right, bias free, agency problems are easily solved and provision of proper monitoring to manage the resources of the firms. In another studies by Cannella et al. (2003), it was concluded that, the occurrence of various directors that are independent could safeguard a firm from bankruptcy. It has also been observed that, the performance of firms significantly affect the board independence in a positive way (Wu, et al., 2009). It was however suggested that, the occurrence of independent directors could bring about better performance of firms. Therefore, the hypothesis is as follow:

H1: A positive coexistence does take place between company's performance and independent directorates.

\subsubsection{Board Size}

The size of BoDs is not easy to be determined. On the point of view from agency theory, boards of bigger size are characterized by a complex structure of decision making process and coordination and this could in turn lead to poor performance of the firm efficiency. This is because; obtaining reliable information or data to properly act and implement decision may be difficult. So, firm of smaller boards were found to be better (Fama \& Jensen, 1983b; Chiang, 2005). In another way round, the resource dependence theory argued that, firms of bigger board's size could improve the performance of firms, simply because boards of larger size could lead to more members of different professional backgrounds (Guest, 2009; Dhamadasa et al., 2014).

In a study conducted by Yermark (1996), it was revealed that, lager firm's value for board sizes that are small for the fact that, large boards do not have the strength to control or monitor the problem of agency and smaller boards as well (Lasfer, 2006). It was also coned out that, the size of the board could exert a negative effect on the performance of a firm. So to say, smaller board size could be seen better as the cost to run larger boards size is high and expensive to run as there will be need for incentives and rewards. Cheng (2008) in his argument said that, smaller boards size appeared to be possess fast decision-making and better efficiency because it was seen not easy for the firm to achieve consensus and proper arrangement of board meetings. The author further argued that, when the size of the board is bigger, it could not be difficult for the CEOs to dominate the board and possibly the control power of CEO will be increased in their decision-making process (Sanda, et al., 2011). The performance firm has positive correlation with smaller board's size as this goes against boards that large in size. Members with shorter communication distance could assist in improving the decision making process of the board more efficiently, and so, small boards positively influence the performance nature of a given firm as mentioned by Guest in 2009. The current study therefore hypothesized as given below:

H2: The presence of negative effect between company performance and the size of directorate.

\subsubsection{Board Meetings}

Agency theory as an approach to monitor (Fama and Jensen, 1983b), would serve as a factor to frequently improve board meetings with the aim of attaining better firm's performance and governance activity at large (Bathula, 2008 and Vafeas, 1999). And contrary to this, the theory guiding stewardship made a suggestion that the by the directorates can be seen less important towards the mandate implementation of a governance board in the sense that, monitoring evaluation was an endogenous process entirely (Hahn and Lasfer, 2007). For this reason, there could be at all level a negative correlation between the firm's performance board and meeting conducted by the directorates.

To deliberate about the condition of the company was the main aims of actualizing these meetings together with the discussion on any matter or suggestions that could come up. Various researches has been conducted to evaluate the frequency of board meetings and how they affect the performance of firm. The frequency of Board meetings was found to be related is positively to the performance of firm, especially, with poor supervising and experiences (Tong, et al., 2013; Brick \& Chidambaran, 2007). Also from another study, a positive linkage was found to be associated with the performance of the firm, due to the fact, meeting's frequency was a monitoring means and this led to an value system of the firm ( Ntim and Osei, 2011). Therefore, the present research suggests that:

H3: There is a positive relationship between the company's performance and frequency of meetings by the board members. 


\subsubsection{Structure Leadership (CEO Duality)}

Theory of agency argued that, CEO duality had good potentials to create many for CEOs to prosper in their decision-making processes. More so, it was seen not to be easy to provide evidence on if the chairman of CEO could better deliver his independent duties aside from his own self-interest (Boonyawat, 2013). As a matter of fact, CEO duality could minimize the efficiency of monitoring duties from the board and subsequently give allowance to the CEOs to be on top of the board (Jensen, 1993). Meanwhile, stewardship theory believed that, the decision-making activities by CEO's duality can be executed efficiently and faster in response to the environmental change of a firm (Boyd, 1995).

Many efforts have tried to observe some relationship that could occur between the performance of a firm and CEO duality. Emphasis could be seen from the work of Omran, et al. (2008) where the performance of the firm indicated no significant difference between chairman and CEO duties. Meanwhile in another research, the effects of CEO.s on firm's performance duality revealed a positive relationship based on separate boards that better the performance of the firm (Weir et al., 2002; Desoky and Mousa, 2012; Kajola, 2008; Haniffa and Hudaib, 2006). The authors however claimed that, the duality is responsible for legal system to be poor and weak within the internal control unit of the firms. The present study however hypothesizes that:

\section{H4: There is a positive relationship between the CEOs dual and companies in their performance ability.}

\subsection{Audit Committees Characteristics}

\subsubsection{Audit Committee Size}

The primary category of the AC's size better monitoring and improvement of firm's performance could be achieved by an increasing number of members. Some authors argued that, larger audit committees of a firm could impact negatively on governance. The work of Sharma et al. (2009) revealed that, the frequency of meetings by AC was negatively associated to numerous executive directors, and to independent AC. Further to this, a positive significant different among the size of $\mathrm{AC}$ size, risk of financial misreporting that are high, financial expertise, institutional and managerial ownership and was revealed.

A negative relationship between firm performance and the size of AC has been revealed by Bozec (2005); Mollah and Talukdar (2007) and Al-Matari et al. (2012). Aside that, the following authors affirmed similar results: (Reddy et al. 2010; Al-Matari et al. 2012; Bauer et al. 2009; Gondrige et al. 2012).

\section{H5: There is presence of a positive relationship between company performance and audit committee size.}

\subsubsection{Audit Committee Financial Expertise}

In line with the Corporate Governance Code (CCC), on the expertise, "the board must always meet up itself for at least an AC member with a relevant and updated financial experience." Research conducted recently revealed that, highly experienced personnel in accounting characterised by reliable governance within boards could generate better monitoring process by the AC which subsequently leads to an improved conservatism (Krishnan and Visvanathan, 2008).

In every AC, it is well known that, the chair can fulfil an important role of leadership and as a matter of fact must remain as highly qualified personnel on the AC. The work by Spira (1999) claimed that, in situation where an AC chair possesses enough background in auditing; there are more tendencies that, the CFO and the chair could bring about a working relationship of better form. Although it was known that, the ACs should have good knowledge, and contrary to this DeZoort (1998) stated that, almost $76 \%$ of AC chairs did possess poor auditing knowledge.

It should be recalled that, experience or knowledge alone could not be enough for financial expertise to be established. Education and experiences are collectively essential to be qualified as a financial expert (Giacomino et al., 2009). Studies related to field of interest are minimal due to poor nature of disclosing cogent information on careers and backgrounds of directors before the boom of post-Enron governance regulatory. Examples of prior research that revealed a positive relationship between firm's performance and AC expertise are the work of Rashidah and Fairuzana (2006) and that of Hamid and Aziz (2012).

\section{H6: There is a positive relationship between the expatriate of financial audit committee and company performance}

\subsubsection{Audit Committee Independence (ACI)}

The ACI possess some merits but also associated with some disadvantages. It was however argued that, the possession of ACI in any given corporation could make the financial reporting to be monitored effectively (Carcello and Neal, 2003) and that of external auditing as well (Abbott et al., 2002; 2004; Beasley, 1996; Carcello and Neal, 
2003). A complete separation from management may allow the members of ACI to poorly identify issues related to industry and poor discussion and negotiations with irregular meetings. All these put together lead to poor monitoring activities as mentioned by Sharma et al. (2009).

Previous research revealed that, the chairs of the AC remain independent and highly experienced personnel of the committee because of the vital role the chair could play in an ideal system. From the work of Sharma et al. (2009), it has been indicated that, certain firms appointed internal director as the AC chair, as this in turn make ACI to be poor. Cotter and Silvester (2003) on their findings concluded that, directors on audit committees that are independent had the tendency to monitor in poor manner by debt-holders with low leverage. However, increased monitoring by debt-holders could arise from executives on the AC. More so, a CEO or board chair placed over AC could minimize the general efficiency of an AC (Beasley and Salterio, 2001). It should be noted that, studies on the relation between $\mathrm{ACI}$ and the performance of the firm are minimal.

Some of the studies related to this issue postulated a positive significant difference between firm performance and ACI (Dey, 2008; Yasser et al. 2011 and Nuryanah and Islam, 2011). While the of, Dar et al. (2011) negate to such study as the authors argued that, there was no positive relationship between ACI and variables chosen to test the performance of the firm.

\section{H7: There is a positive relationship between audit committee independence and company performance.}

\section{Methodology of Research}

\subsection{Data}

The Amman Stock Exchange (ASE) is made up of 240 listed companies allocated under 3 sectors (Industry, Financial and Services). The financial sector was excluded in this study, simply for the fact that, nature of the mechanisms corporate governance and financial firms needs to be differently applied in sectors of finance (Dalwai, et al., 2015; Abed, 2012). Also, diverse set of rules and regulation governed firms in this sector and thus incomparable is form under other sectors (Marashdeh, 2014; Abed et al., 2012). The works of Al-Matari, et al. (2014) argued that, both the financial firms and non-financial firms made use of various approach with various structures.

The present research covers 2 sectors of ASE; sectors of industry and services representing for about $60 \%$ (i.e. 150 companies) listed companies. A total number of 80 firms of industry sector were involved representing $32 \%$ of ASE firms, 70 services sectors representing $28 \%$ of ASE firms. It should be known that, 10 firms were excluded from the sampling (i.e. 7 services firms and 3 industrial firms). Thus, 140 firms were observed. The time frame to carry the research was from 2015 to 2019 (4years).

\subsection{Definitions of Variables}

Table 1. Definitions of the variables

\begin{tabular}{|c|c|c|}
\hline VARIABLE & ACRONYM & MEASUREMENT \\
\hline \multicolumn{3}{|l|}{ Dependent Variables } \\
\hline Return on assets & ROA & Net income to total assets \\
\hline \multicolumn{3}{|l|}{ Independent Variables } \\
\hline Board of director independence & BDI & Proportion of independent members \\
\hline Board size & BSIZE & $\begin{array}{l}\text { Natural logarithm of total number of board of directors } \\
\text { members }\end{array}$ \\
\hline Board of directors meetings & $\mathrm{BDM}$ & $\begin{array}{l}\text { Natural logarithm of total number of board of directors } \\
\text { meetings over the year. }\end{array}$ \\
\hline Leadership structure & CDUAL & $\begin{array}{l}\text { Dummy variable takes one if the chairman not holds } \\
\text { the position of CEO, otherwise zero. }\end{array}$ \\
\hline Audit Committee Size & ACSIZE & Number of audit committee members \\
\hline $\begin{array}{l}\text { Audit Committee Financial } \\
\text { Expertise }\end{array}$ & ACFINEXP & $\begin{array}{l}\text { Proportion of audit committee members with financial } \\
\text { expertise over the total number of audit committee } \\
\text { members }\end{array}$ \\
\hline Audit Committee Independence & ACINDEP & $\begin{array}{l}\text { Proportion of independent directors over overall audit } \\
\text { committee size }\end{array}$ \\
\hline
\end{tabular}




\subsection{Model Development}

The present study made use of the panel data approach as this could get rid of unobservable heterogeneity as various companies from data sample can present poor collinearity among the variables and pure time series or pure cross section data were better measured (Gujarati, 2009). Approach to testing the hypotheses of the two clusters of independent variables (IV) (Audit Committees Characteristics and Board of directors Characteristics) on the dependent variable (DV) (Company Performance) among the listed companies in Jordan is as below:

$$
R O A=a+\beta_{1} B D I_{i t}+\beta_{2} \text { BSIZE }_{i t}+\beta_{3} B D M_{i t}+\beta_{4} C D U A L_{i t}+\beta_{5} A C S I Z E_{i t}+\beta_{6} A C F I N E X P+\beta_{7} A C I N D E P_{i t}
$$

Where: ROA stands for company's performance representing the dependent (variable DV). The characteristics of BoDs involves the some variables as follow: Board's size (BSIZE), leadership structure (CDUAL), Directors independence (BDI ), Board meetings (BDM) and the audit committees characteristics stands for these variables: audit committee independence (ACINDEP), audit committee expertise (ACFINEXP) and audit committee size (ACSIZE).

\subsection{Dynamic Panel Generalized Method of Moments (GMM)}

The GMM model as approach in this study was considered in a dynamic panel. This model (GMM) as adopted by Blundell and Bond (1998) and Arellano and Bover (1995), improved the first difference GMM efficiently. The model of GMM addressed the possible effects of company's performance in the past on the existing companies. For the purpose of sampling, this method made use of shorter under huge numbers of firms. Basically There the GMM model comprises of 2 level equations, and from the first difference, every equation adopted an Instrumental Variables (IV) to remove the correlation between residuals and explanatory variables.

There is a positive significant effect by adopting GMM approach in the handling of short-sample periods, heterogeneity, autocorrelation, explanatory variables and heteroskedasticity that were predetermined and endogenous. As a case sample, the estimation potential would dramatically be improved under this GMM approach. It is then necessary to note that, the adoption of suitable instruments remain paramount in ensuring a successful process of GMM estimator in a consistent and efficient manner. In this regard, the test of Hansen/Sargan of over identifying restrictions, AR (2), and the difference in Hansen test were the 3 tests of an appropriate diagnostic.

More so, the test of Hansen/Sargan in over-identifying restrictions carefully scrutinised the whole validity of instruments. This could be realised through proper examination of the moment conditions' sample analogue used in the process of estimation. In this way, it is assumed that, the instruments are valid and the approach is correctly specified by holding the moment condition. On the other hand, the AR (2) test of performs on residuals was also used just to make sure that, there is no presence of serial correlation in terms of transformative errors. Finally, the Hansen test difference is meant to evaluate properly the validity condition of extra moment on the GMM system. T variation among the Hansen statistic test generated by the GMM model and the difference in GMM was measured. As the 3 null hypotheses failed to be rejected, the estimated model is believed to be in support.

\section{Results}

\subsection{Descriptive Analysis}

From the present research, the ROA was used as a measure for the performance of the companies. The descriptive analysis on the performance of companies measures of the samples were depicted below as indicated in Table 2 . The ROA highest value was closer to $(84 \%)$ whereas $(-44)$ was the lowest value with a mean value $(1.75 \%)$ for total samples. When considering the variables of BoDs, the mean value of independent board was 0.37 which was compiled from the recommendations of JCGC signifying that, at least $1 / 3$ of the board members were independent. The finding from this study was seen higher compared to the study revealed by Marashdeh (2014). It seems therefore that, companies in Jordanian tend to be committed better with the corporate governance (CG) rules after establishing code of CG in year 2009. According to Alwshah (2009), the average board's size was estimated to be 8.06 members with a at least 3 but 13 as highest for all samples, and this fact is in supports of the studies conducted by Idris (2012) and also from work of Zedan and Abu Nassar (2014) in Jordan.

As mentioned by JCGC, the BoDs would need to meet in one year for at least 6 times. For at least 3 and a maximum of 13 for the all samples, this research observed that, the board meetings on average was (7.40) each year as this was comparable to the recommendations given by JCGC which revealed that, in every year the BoDs should meet for a minimum of 6 times. The result from the current study was however observed to be better as compared to the work of Al Daoud et al. (2015) and that of Marashdeh (2014). 
The members of AC comprised of 4 members in Jordanian Companies. The member of least value of the AC was (4) as this was legally required. Meanwhile the highest required was 8 . On average, $41 \%$ of AC members were characterised by relevant and updated financial experience and almost $98 \%$ of the members were seen as independent pursuant to the Corporate Governance Code CCC. In Jordan the size of the firms was around 0.92\%, and an average of $0.87 \%$ firm's leverage

Table 2. Descriptive analysis on company performance

\begin{tabular}{lllllll}
\hline Variables & Mean & Maximum & Minimum & Std. D & Skewness & Kurtosis \\
\hline ROA & 1.75 & 84 & -44 & 10.14 & -0.35 & 2.44 \\
\hline BDI & 0.37 & 1 & 0 & 0.17 & 0.83 & 0.18 \\
\hline BSIZE & 8.06 & 13 & 3 & 2.22 & 0.30 & -0.49 \\
\hline BDM & 7.40 & 23 & 5 & 1.84 & 0.97 & 0.39 \\
\hline CDUAL & 0.63 & 1 & 0 & 0.48 & -053 & -1.02 \\
\hline ACSIZE & 0.46 & 42 & 0 & 0.28 & 0.10 & -1.02 \\
\hline ACFINEXP & 71462430 & 1765784380 & 469848 & 185668841.97 & 5.17 & 30.82 \\
\hline ACINDEP & 0.35 & 2 & 0 & 0.25 & 0.88 & 0.33 \\
\hline
\end{tabular}

\subsection{Diagnostic Tests}

Multivariate regression has been used as a model to analyse hypotheses, assumptions of normality, homoscedasticity, autocorrelations and multicollinearity. I should be made known that, the present study adopted the model Skewness and Kurtosis tests on the normality test, the data output was considered normal only if the standard skewness was within the range of \pm 1.96 with the value of standard kurtosis to be \pm 3 as observed by Haniffa \& Hudaib (2006). The results presented in Table 2, indicated an acceptable range value $( \pm 1.96)$ of skewness with the exception on that of audit committee independence value (5.17) which exceeded the recommendable range value $( \pm 1.96)$. This revelation agreed with the standard kurtosis statistics for the acceptable normal range value $( \pm 3)$ but the value of audit committee independence which was 30.82 was nullified as this exceeded the approved range value $( \pm 3)$.

As the audit committee independence is in violation with the normality assumption, steps on data transformations were undertaken. In a study conducted by Hair et al. (2009), the occurrence of multicollinearity of the correlation that is taken place among two independent variables with a value exceeding 0.90. Additionally, considering the correlation matrix, the variance inflation factor (VIF) was adopted in this study to analyse the multicollinearity. In line with the study of Gujarati (2009), an indication of higher degree of multicollinearity is tantamount to the value of VIF that is greater than 10 and there is there is no any problem of multicollinearity problem as presented in Table 3 in this study.

Table 3. Correlation matrix and VIF results

\begin{tabular}{|c|c|c|c|c|c|c|c|c|c|}
\hline & ROA & BDI & BSIZE & BDM & CDUAL & ACSIZE & ACINDEP & ACFINEXP & VIF \\
\hline ROA & 1 & & & & & & & & \\
\hline BDI & $-.087 *$ & 1 & & & & & & & 1.17 \\
\hline BSIZE & $.115^{* *}$ & $.235 * *$ & 1 & & & & & & 1.31 \\
\hline BDM & -.057 & .061 & .039 & 1 & & & & & 1.03 \\
\hline CDUAL & $-.106^{* *}$ & $.159^{* *}$ & -.024 & -.045 & 1 & & & & 1.04 \\
\hline ACSIZE & $.162 * *$ & $-.180 * *$ & .038 & -.004 & -.042 & 1 & & & 1.07 \\
\hline ACFINEXP & $.345^{* *}$ & -.047 & $.388 * *$ & $.080^{*}$ & -.009 & -.017 & 1 & & 1.32 \\
\hline ACINDEP & $-.240 * *$ & .001 & -.001 & $.138 * *$ & $.086^{*}$ & $-.151^{* *}$ & $.261^{* *}$ & 1 & 1.14 \\
\hline
\end{tabular}




\section{Regression Results}

The model of fixed-effects regression was used for this research as suggested by adopted test of Hausman. Based on the model of statistic of regression, analysis on the explanatory power of research model and statistically significant in testing where $\mathrm{p}<0.01$, which suggests better in the regression for ROA.

$$
\begin{gathered}
R O A=6.20+0.733 B^{B D I} I_{i t}-0.285 B S I Z E_{i t}-0.188 B D M_{i t}-0.651 C D U A L_{i t}+1.265 A_{C S I Z E_{i t}} \\
+1.788 \text { ACFINEXP }-5.825 \text { ACINDEP }_{i t}
\end{gathered}
$$

Table 4. The effect of board of directors and audit committee characteristics on company performance

\begin{tabular}{lll}
\hline Variables & Coefficients & P-value \\
\hline Constant & 6.200 & $0.0017^{* * *}$ \\
\hline BDI & 0.733 & $0.0000^{* * *}$ \\
\hline BSIZE & -0.285 & $0.0284^{* *}$ \\
\hline BDM & -0.188 & 0.1492 \\
\hline CDUAL & -0.651 & 0.4008 \\
\hline ACSIZE & 1.265 & 0.3342 \\
\hline ACFINEXP & 1.788 & $0.0000^{* * *}$ \\
\hline ACINDEP & -5.825 & $0.0000^{* * *}$ \\
\hline Adjusted R2 & 0.468226 & \\
\hline F-statistic & $39.341^{* * *}$ & \\
\hline
\end{tabular}

A positive relationship was shown in Table 4 between the independent BoDs and the ROA under 1\% level. This implies that the directors characterise by greater independence could improve better the performance of firm. The size of the board was found to be negatively significant under 5\% level, the signifying an increasing level directorates size which could render a poor performance to any company. This outcome agreed to results of the studies conducted earlier on (Britton \& Waterston, 2006; Guo \& Kga, 2012; Darko, et al., 2016; Haniffa \& Hudaib, 2006; Yermark, 1996; Akpan, 2015; Switzer \& Tang, 2009) and the authors mentioned that, boards of bigger size did not take a part effectively to the actual management process rather than been symbolic instead of being.

However, no significant difference was revealed from the findings between the BoDs meeting, structure of leadership and the performance of the firms as evaluated by the ROA. Signs of coefficient as relate to variables in question were not consistent under expectations.

Still from similar table (table 4) the size of audit committee size and audit committee expertise give out has a positive significant difference at 5\% level with the ROA. This claim was similar to claim made by Bauer et al. (2009) and Rashidah and Fairuzana (2006); Dar et al. (2011) and (Yasser et al. (2011), where the independent AC was negatively significant with the ROA at $5 \%$ level.

\subsection{Results Discussion}

Hypothesis one (H1) predicted a positive relationship between the firm performance and independent directors. The sign of coefficients remain consistent with expected result. A positive significant difference was observed to influence ROA from the outcome of this study. This observation was similar to the perspective of agency theory, which emphasised that, the manifestation of big level of independent directors in a given board had the tendency foster more advantages to a company through the provision of independent and reliable decisions and good judgments to the company. Furthermore, the still remain similar to the theory of resource dependence, where the external occurrence on the board could generate an entering of skills that are novel, information and suppliers by enhancing the gaining ability of sources as revealed by Hillman and Dalziel (2003). Similar to pass research conducted by Duchin et al. (2010) and Coles et al. (2012), where they authors found out that, independent directors positively had effects on the performance ability of a company.

On hypothesis two (H2), it was suggested that, a negative relationship occur between the firm performance and board's size. The findings indicated a negative significant difference between the size of the board and ROA. The 
sign of coefficient was however consistent based on expected results. The present study agreed on the view of agency theory, in which smaller boards reach consensus most often and also give room for members to engage in cogent or genuine interactive debate but larger boards could coordination and make decision in more complex and difficult manner thereby leading to poor performance and efficiency (Fama \& Jensen, 1983b; Chiang, 2005). In case of smaller board, the short distance communication among members could improve better the efficiency of board in their decision-making process as mentioned by Guest (2009). Contrary to other pass works (Britton \& Waterston, 2006; Guo \& Kga, 2012; 2006; Switzer and Tang, 2009; Yermark, 1996; Akpan, 2015; Haniffa et al., 2016) it was revealed that, boards of bigger size do not impact positively since they do not involved to the process of actual management by being symbolic.

Hypothesis (H3) represents meetings of board of directors and suggested that, the frequency of meeting by board of directors positively impact on performance. The outcome postulated an insignificant relationship on ROA. The perspective theory of agency is in same agreement from this claim, as the main duty performed by the board of directors was proper management and monitoring process to absorb problems faced by the agency, while the features of BoDs could occur when board often meets leading to the overall performance of the board. The results based on past research as mention by Tong et al. (2013) and Ntim and Osei (2011) were similar as the authors found out that, the rate at which meetings were held by the board could influence the performance especially if the management lack enough experience with poor supervision. This negative impact could have been caused by more expenses like the high costs from the board meetings, together with cost of travelling, hotel accommodation, and other fees related directors' meeting (Brick \& Chidambaran, 2007).

Regarding the 4th hypothesis (H4), it was suggested, firm performance could positively be influenced by the actions of separating leadership role. It should be known that, there was no significant difference between the firm performance and leadership structure based on the statistical analysis obtained from this study. This implies that, no notable difference on the performance among the companies following the duality and that of separation the role by the chairman and CEO. The present study is however in support of the work of Mustapa (2013), who mentioned that the relationship between firm's performance and the leadership structure was insignificant.

Based on 5th hypothesis (H5), there came up significant effect that was positive among the size of AC size and the firm's performance do exist. Output from this study is in line with $\mathrm{H} 5$ and it means that, the size of AC influence the firm's performance positively and also back up with the study of conducted by Bauer et al. (2009), in which the authors discovered similar positive significant relationship between the size of AC and the performance of the firm.

More so, concerning the 6th hypothesis (H6) it was predicted that, the financial expertise of AC members had positive impact on the firm's performance. Based on the analytical regression model, it was found out that there is positive significant difference between both chosen variables and this confirm a true hypothesis. It was however suggested that, the Jordanian companies could better perform their financial process accordingly if the member are better trained on relevant and recent financial knowledge (Rashidah and Fairuzana, 2006). The same author went further to reveal the positive impact of the AC financial experience on 100 Malaysian companies. The outcome of their work however indicated significant improvement.

On the final hypothesis (H6) predicted that, as the independent AC becomes greater, the higher the performance of the firm. It was compiled from present study that, a negative significant difference could exist between AC independence and the firm. This claim did not support the work of Yasser et al. (2011) as the authors found out a positive relationship between them. For this reason, it could be said that, independent directors suffer more often from insufficient or lack experience about a business capable to bring about useful advice to the board of directors to improve financial performance of the firm.

\section{Conclusion}

The basic behind this research was to properly evaluate relationship between BoDs' characteristics variables which include board of directors' independence, size of the board, board meetings and structure of leadership), characteristics of audit committee variables (audit committee independence, audit committee size and audit committee expertise) and the performance of company measures accounting (ROA) returns for the Jordanian firms. A total number of 140 non-financial firms as data employed in this study listed on ASE over 4 years (i.e. between 2015-2019).This research was motivated due to controversial debate in the past studies couple with limited data available considering the developing nations as case sample. Emphasis was therefore made in Jordanian firms. The present study however shed more light from the output of analyzed data to determine impact of BoDs characteristics and SC characteristics over the performance of the firm. Generally speaking, the analysis agreed to the view of agency theory most especially in terms of board size, audit committee independence, audit committee size audit 
committee expertise and board independence. It must be made known that; the results from the current research are in similar agreement to some of the studies carried out earlier on.

The findings from the present research finalized that, the effects of BoDs and AC features over the performance ability of firms in Jordan could remain a critical factor to consider on measurement of performance characteristics. The outputs differed in accordance to the firm's performance been measured. More research are still welcome on other mechanisms of corporate governance, like transparency and disclosure, the composition of board, diversity of the board and structure of ownership. All these put into consideration, would possibly impact the general performance of a firm. More so, the moderating variables (directors' demographic characteristics, family control and shariah approved company) must as well be put into consideration.

Lastly, this study is a considerable addition to the company performance and financial reporting arena particularly in terms of the issue of board of directors and audit committee. This study specifically focuses on the factors that determine the performance of company and financial reports among the ASE listed companies operating in Jordan. It is hoped that this effort would motivate more studies on the topic of corporate governance and company performance in the context of other nations because clearly, the subject in question still requires significant amount of exploration. Furthermore, the outcomes generated are also of value to investors, legislators as well as decision-makers.

\section{References}

Abed, S., Al-Attar, A., \& Suwaidan, M. (2012). Corporate governance and earnings management: Jordanian evidence. International Business Research, 5(1), 216. https://doi.org/10.5539/ibr.v5n1p216

Achim, M.-V., Borlea, S.-N., \& Mare, C. (2016). Corporate governance and business performance: evidence for the Romanian economy. Journal of Business Economics and Management, 17(3), 458-474. https://doi.org/10.3846/16111699.2013.834841

Adebayo, O. S., Olusola, A. G., \& Abiodun, O. F. (2013). Relationship between corporate governance and organizational performance: Nigerian listed organizations experience. International Journal of Business and Management Invention, 2(9), 1-6.

Aduda, J., Chogii, R., \& Magutu, P. O. (2013). An empirical test of competing corporate governance theories on the performance of firms listed at the Nairobi securities exchange. European Scientific Journal, 9(13), 107-137.

Akbar, A. (2015). The role of corporate governance mechanism in optimizing firm performance: a conceptual model for corporate sector of Pakistan. Journal of Asian Business Strategy, 5(6), 109-115.

Akpan, E. O. (2015). Corporate board meetings and company performance: empirical evidence from Nigerian quoted companies. Global Journal of Commerce \& Management Perspective, 4(1), 75-82.

Al Daoud, K. A., Ismail, K. N. I. K., \& Lode, N. A. (2015). The impact of internal corporate governance on the timeliness of financial reports of Jordanian firms: evidence using audit and management report lags. Mediterranean Journal of Social Sciences, 6(1), 430. https://doi.org/10.5901/mjss.2015.v6n1p430

Al Ramahi, N., Alaboud, E., Owais, W., AlRefae, K., \& Shahwan, Y. (2014). The results of applying the principles of corporate governance in corporations listed on the first market in the Amman stock exchange. Research Journal of Finance and Accounting, 5(14), 41-53.

Albrecht, W. S., Albrecht, C. C., \& Albrecht, C. O. (2004). Fraud and corporate executives: agency, stewardship and broken trust. Journal of Forensic Accounting, V, 109-130.

Al-Kassar, T. A., \& Al-Nidawiy, M. A. (2014). The role of corporate governance and its impact on the share price of industrial corporations listed on the Amman stock exchange. European Journal of Accounting Auditing and Finance Research, 2(6), 106-123.

Almasarwah, A. K. (2015). Earnings management and its relationship with corporate governance mechanisms in Jordanian industrial firms. PhD Thesis, Loughborough University.

Al-Matari, E. M., Al-Swidi, A. K., \& Fadzil, F. H. B. (2014). The effect of board of directors characteristics, audit committee characteristics and executive committee characteristics on firm performance in Oman: an empirical study. Asian Social Science, 10(11), 149. https://doi.org/10.5539/ass.v10n11p149

Alwshah, K. A. A. M. (2009). The impact of corporate governance and ownership structure on performance and financial decisions of firms: evidence from Jordan. PhD thesis, University of Hull. 
Amran, A., Ishak, M. S., Zulkafli, A. H., \& Nejati, M. (2010). Board structure and extent of corporate governance statement. International Journal of Managerial and Financial Accounting, 2(4), 383-400. https://doi.org/10.1504/IJMFA.2010.035639

Amran, N., \& Ayouib, A. (2011). Board mechanisms and Malaysian family companies' performance. Asian Journal of Accounting and Governance, 2, 15-26. https://doi.org/10.17576/ajag-2011-2-6538

Anderson, R., \& Reeb, D. (2004). Board composition: balancing family influence in S\&P 500 firms. Administrative Science, 49(2), 209-237.

Arora, A. (2015). Literature review assessing the relationship between corporate governance and firm performance. Paper presented at the Compendium of Research Papers of National Conference on managing tomorrow: Issues and Challenges by DY Patil Institute of Management Studies, Pune.

Arora, A., \& Sharma, C. (2016). Corporate governance and firm performance in developing countries: evidence from India. Corporate Governance, 16(2), 420-436. https://doi.org/10.1108/CG-01-2016-0018

Bathula, H. (2008). Board characteristics and firm performance: evidence from New Zealand. PhD thesis, Auckland University of Technology.

Bhagat, S., \& Bolton, B. (2008). Corporate governance and firm performance. Journal of Corporate Finance, 14, 253-273. https://doi.org/10.1016/j.jcorpfin.2008.03.006

Bhagat, S., \& Bolton, B. (2009). Corporate governance and firm performance: recent evidence. https://doi.org/10.2139/ssrn.1361815

Bhagat, S., \& Bolton, B. (2013). Director ownership, governance, and performance. Journal of Financial and Quantitative Analysis, 48(1), 105-135. https://doi.org/10.1017/S0022109013000045

Black, B. S., Jang, H., \& Kim, W. (2006). Does corporate governance predict firms' market values? Evidence from Korea. Journal of Law, Economics, and Organization, 22(2), 366-416. https://doi.org/10.1093/jleo/ewj018

Boonyawat, K. (2013). The impact of ownership structure and other corporate governance mechanisms on firm performance, accounting discretions and investor perceptions: evidence from Thailand before and after the corporate governance reforms. PhD thesis, Durham University.

Boyd, B. K. (1995). Ceo Duality and firm performance: a contingency model. Strategic Management Journal, 16(4), 301-312. https://doi.org/10.1002/smj.4250160404

Brick, I. E., \& Chidambaran, N. K. (2007). Board meetings, committee structure, and firm performance. https://doi.org/10.2139/ssrn.1108241

Britton, A., \& Waterston, C. (2006). Financial accounting (4th ed.). Prentice Hall, Harlow.

Brown, L. D., \& Caylor, M. L. (2009). Corporate governance and firm operating performance. Review of Quantitative Finance and Accounting, 32(2), 129-144. https://doi.org/10.1007/s11156-007-0082-3

Cheng, S. (2008). Board size and the variability of corporate performance. Journal of Financial Economics, 87(1), 157-176. https://doi.org/10.1016/j.jfineco.2006.10.006

Chiang, H. (2005). An empirical study of corporate governance and corporate performance. Journal of American Academy of Business, 31(1), 122-140.

Coles, J. L., Danielb, N. D., \& Naveen, L. (2012). Boards: does one size fit all?. Journal of Financial Economics, 87(2), 329-356. https://doi.org/10.1016/j.jfineco.2006.08.008

Daily, C. M., Dalton, D. R., \& Cannella, A. A. (2003). Corporate governance: decades of dialogue and data. Academy of Management Review, 28, 371-382. https://doi.org/10.5465/amr.2003.10196703

Dalwai, T. A. R., Basiruddin, R., Abdul Rasid, S. Z., Kakabadse, N., \& Fleur, M. (2015). A critical review of relationship between corporate governance and firm performance: gcc banking sector perspective. Corporate Governance: The International Journal of Business in Society, 15(1), 18-30. https://doi.org/10.1108/CG-04-2013-0048

Darko, J., Aribi, Z. A., Uzonwanne, G. C., Eweje, G., \& Eweje, G. (2016). Corporate governance: the impact of director and board structure, ownership structure and corporate control on the performance of listed companies on the Ghana stock exchange. Corporate Governance: The International Journal of Business in Society, 16(2). https://doi.org/10.1108/CG-11-2014-0133 
Desoky, A. M., \& Mousa, G. A. (2012). Do board ownership and characteristics affect on firm performance? evidence from Egypt. Global Advanced Research Journal of Economics, Accounting and Finance, 1(2), 15-32.

Dhamadasa, P., Gamage, P., \& Herath, S. K. (2014). Corporate governance, board characteristics and firm performance: evidence from Sri Lanka. South Asian Journal of Management, 21(1), 7-31.

Duchin, R., Matsusaka, J. G., \& Ozbas, O. (2010). When are outside directors effective?. Journal of Financial Economics, 96(2), 195-214. https://doi.org/10.1016/j.jfineco.2009.12.004

Duztas, S. (2008). Corporate governance: the effects of board characteristics, information technology maturity and transparency on company performance. Ph.D Thesis, Yeditepe University.

El-Faitouri, R. (2014). Board of directors and Tobin's q: evidence from UK firms. Journal of Finance and Accounting, 2(4), 82-99.

Emile, R., Ragab, A., \& Kyaw, S. (2014). The effect of corporate governance on firm performance, evidence from $\begin{array}{lllll}\text { Egypt. Asian Economic and Financial Review, } & 4(12), & 1865-1877 .\end{array}$ https://doi.org/10.18488/journal.aefr/2014.4.12/102.12.1865.1877

Fama, E. F., \& Jensen, M. C. (1983a). Agency problems and residual claims. Journal of law and Economics, 26(2), 327-349. https://doi.org/10.1086/467038

Fama, E. F., \& Jensen, M. C. (1983b). Separation of ownership and control. Journal of law and Economics, 26(2), 301-325. https://doi.org/10.1086/467037

Fooladi, M., \& Shukor, Z. A. (2012). Board of directors, audit quality and firm performance: evidence from Malaysia. Paper presented at the National Research \& Innovation Conference for Graduate Students in Social Sciences (GS-NRIC 2012), Melaka. Retrieved from http://ssrn.com/abstract=2259523

Guest, P. (2009). The impact of board size on firm value: evidence from the UK. The European Journal of Finance, 15(4), 385-404. https://doi.org/10.1080/13518470802466121

Gujarati, D. N. (2009). Basic econometrics (5th ed.). New York: McGraw-Hill.

Guo, Z., \& Kga, U. K. (2012). Corporate governance and firm performance of listed firms in Sri Lanka. Procedia-Social and Behavioral Sciences, 40, 664-667. https://doi.org/10.1016/j.sbspro.2012.03.246

Hahn, P. D., \& Lasfer, M. (2007). Vanishing board meetings: has governance doomed the board meeting. London: Cass Business School Research Paper.

Hair, J. F., Black, W. C., Babin, B. J., \& Anderson, R. E. (2009). Multivariate data analysis (7th ed.). New Jersey: Person Prentic Hall.

Haniffa, R., \& Hudaib, M. (2006). Corporate governance structure and performance of Malaysian listed companies. Journal of Business Finance \& Accounting, 33(7-8), 1034-1062. https://doi.org/10.1111/j.1468-5957.2006.00594.x

Hillman, A. J., \& Dalziel, T. (2003). Boards of directors and firm performance: integrating agency and resource dependence perspectives. Academy of Management Review, 28(3), 383-396. https://doi.org/10.5465/amr.2003.10196729

Horner, S. V. (2010). CEO duality as a double-edged sword: how boards of directors balance entrenchment avoidance and unity of command. Academy of Management Journal, 37(5).

Horvath, R., \& Spirollari, P. (2012). Do the board of directors' characteristics influence firm's performance? The U.S. Evidence. Prague Economic Papers, 470-486. https://doi.org/10.18267/j.pep.435

Hu, H. W., Tam, O. K., \& Tan, M. G.-S. (2010). Internal governance mechanisms and firm performance in China. Asia Pacific Journal of Management, 27(4), 727-749. https://doi.org/10.1007/s10490-009-9135-6

Idris, M. I. I. (2012). The impact of ownership structure and external audit on accruals and real activities earnings management in Jordan. PhD Thesis, University of Gloucestershire.

Jaafar, A., \& El Shawa, M. (2009). Ownership concentration, board characteristics and performance: evidence from Jordan. In M. Tsamenyi, \& S. Uddin (Eds.), Accounting in emerging economies (research in accounting in emerging economies) emerald group publishing limited (Vol. 9, pp. 73-95). https://doi.org/10.1108/S1479-3563(2009)0000009005 
JCGC. (2008). Jordanian corporate governance code. Jordan Security Commission. Retrieved February 3, 2015, from http://jsc.gov.jo/library/634365426651890968.pdf

Jensen, M. (1993). The modern industrial revolution, exit, and the failure of internal control systems. The Journal of Finance, 48(3), 831-880. https://doi.org/10.1111/j.1540-6261.1993.tb04022.x

Jensen, M. C., \& Meckling, W. H. (1976). Theory of the firm: managerial behavior, agency costs and ownership structure. Journal of Financial Economics, 3(4), 305-360. https://doi.org/10.1016/0304-405X(76)90026-X

Kajola. (2008). Corporate governance and firm performance: the case of nigerian listed firms European. Journal of Economics, Finance and Administrative Sciences, (14), 16-28.

Kapopoulos, P., \& Lazaretou, S. (2007). Corporate ownership structure and firm performance: evidence from Greek firms. Corporate Governance: An International Review, 15(2), 144-158. https://doi.org/10.1111/j.1467-8683.2007.00551.x

Khorma, T. (2014). The myth of the Jordanian monarchy's resilience to the Arab spring: lack of genuine political reform undermines social base of monarchy. Retrieved December 16, 2016, from https://www.swpberlin.org/fileadmin/contents/products/comments/2014C33_kor.pdf

La Porta, R., Lopez-de-Silanes, F., Shleifer, A., \& Vishny, R. W. (1997). Legal determinants of external finance. The Journal of Finance, 52(3), 1131-1150. https://doi.org/10.1111/j.1540-6261.1997.tb02727.x

Lasfer, M. (2006). The interrelationship between managerial ownership and board structure. Journal of Business Finance \& Accounting, 33(7-8), 1006-1033. https://doi.org/10.1111/j.1468-5957.2006.00600.x

Liang, F.-M. (2009). Ownership structure and firm performance in an emerging market: the moderating role of social networks. Contemporary Management Research, 5(2), 201-212. https://doi.org/10.7903/cmr.1082

Liu, H., \& Fong, M. W. (2010). Board characteristics of medium and large Chinese companies. Corporate Governance: The International Journal of Business in Society, 10(2), 163-175. https://doi.org/10.1108/14720701011035684

Liu, Y., Miletkov, M. K., Wei, Z., \& Yang, T. (2015). Board independence and firm performance in China. Journal of Corporate Finance, 30, 223-244. https://doi.org/10.1016/j.jcorpfin.2014.12.004

Lutfi Iramani, R., \& Silvy, M. (2014). The role of board of commissioners and transparency in improving bank operational effeciency and profitability. Paper presented at the The 3rd International Conference on Business and Banking Pattaya, Thailand. https://doi.org/10.14414/jebav.v17i1.268

Marashdeh, Z. M. S. (2014). The effect of corporate governance on firm performance in Jordan. Ph.D thesis, University of Central Lancashire.

Matar, M., \& Nauimat, Z. (2014). The response of the boards of directors in the distressed Jordanian public shareholding companies to the risk and repercussions of the global financial crisis. Jordan Journal of Business Administration, 10(1). https://doi.org/10.12816/0026182

McIntyre, M. L., Murphy, S. A., \& Mitchell, P. (2007). The top team: examining board composition and firm performance. Corporate Governance: The International Journal of Business in Society, 7(5), 547-561. https://doi.org/10.1108/14720700710827149

Miller, T., \& Triana, M. D. C. (2009). Demographic diversity in the boardroom: mediators of the board diversity-firm performance relationship. Journal of Management Studies, 46(5), 755-786. https://doi.org/10.1111/j.1467-6486.2009.00839.x

Mura, R. (2006). Firm performance: do non-executive directors have a mind of their own? Evidence from UK panel data. Financial Management, 36(3), 81-112. https://doi.org/10.1111/j.1755-053X.2007.tb00082.x

Mustapa, I. R. (2013). The moderating influence of organizational culture and organizational capacity on the association between corporate governance and performance of Malaysian listed companies. PhD Thesis, International Islamic University Malaysia.

Ntim, C. G., \& Osei, K. A. (2011). The impact of corporate board meetings on corporate performance in South Africa. African Review of Economics and Finance, 2(2), 83-103.

Omran, M. M., Bolbolc, A., \& Fatheldin, A. (2008). Corporate governance and firm performance in Arab equity markets: does ownership concentration matter?. International Review of Law and Economics, 28(1), 32-45. https://doi.org/10.1016/j.irle.2007.12.001 
Park, H. M. (2009). Linear regression models for panel data using Sas, Stata, Limdep, and Spss. Indiana University.

Ren, Y. (2014). Corporate governance, conservatism and firm performance: evidence from China. PhD thesis, Edith Cowan University.

Sanda, A. U., Garba, T., \& Mikailu, A. S. (2011). Board Independence and Firm Financial Performance: Evidence from Nigeria. African Economic Research Consortium.

Shukeri, S. N., Shin, O. W., \& Shaari, M. S. (2012). Does board of director's characteristics affect firm performance? Evidence from Malaysian public listed companies. International Business Research, 5(9), 120-127. https://doi.org/10.5539/ibr.v5n9p120

Silva, A. L. C. D., \& Leal, R. P. C. (2005). Corporate governance index, firm valuation and performance in Brazil. Revista Brasileira de Financ, 3(1), 1-18.

Switzer, L. N., \& Tang, M. (2009). The impact of corporate governance on the performance of us small-cap firms. International Journal of Business, 14(4), 341.

The Cadbury Report. (1992). Report of the committee on the financial aspects of corporate governance.

Tong, S., Junarsin, E., \& Davidson, W. N. (2013). A comparison of chinese state-owned enterprise firm's boards and private firm's boards. Paper presented at the 23rd International Business Research Conference, Melbourne, Australia.

Vafeas, N. (1999). Board meeting frequency and firms performance. Journal of Financial Economics, 113-142. https://doi.org/10.1016/S0304-405X(99)00018-5

Wahba, H., \& Zaima, J. (2015). The joint effect of board characteristics on financial performance: empirical evidence from Egypt. Review of Accounting and Finance, 14(1), 20-40. https://doi.org/10.1108/RAF-03-2013-0029

Warrad, L., Almahamid, S. M., Slihat, N., \& Alnimer, M. (2013). The relationship between ownership concentration and company performance, a case of Jordanian non-financial listed companies. Institute of Interdisciplinary Business Research.

Weir, C., Laing, D., \& McKnight, P. J. (2002). Internal and external governance mechanisms: their impact on the performance of large UK public companies. Journal of Business Finance \& Accounting, 29, 579-611. https://doi.org/10.1111/1468-5957.00444

Wu, M.-C., Lin, H.-C., Lin, I.-C., \& Lai, C.-F. (2009). The effects of corporate governance on firm performance. Working paper.

Yermark, D. (1996). Higher market valuation of companies with a small board of directors. Journal of Financial Economics, 40, 185-221. https://doi.org/10.1016/0304-405X(95)00844-5

Zedan, H. I., \& Abu Nassar, M. H. (2014). The effect of corporate governance on operating performance of jordanian manufacturing companies: evidence from Amman stock exchange. Dirasat: Administrative Sciences, 4l(2), 465-481. https://doi.org/10.12816/0007483

Zureigat, B. N., Fadzil, F. H., \& Ismail, S. S. S. (2014). The relationship between corporate governance mechanisms and going concern evaluation: evidence from firms listed on Amman stock exchange. Journal of Public Administration and Governance, 4(4), 100-110. https://doi.org/10.5296/jpag.v4i4.6745

\section{Copyrights}

Copyright for this article is retained by the author(s), with first publication rights granted to the journal.

This is an open-access article distributed under the terms and conditions of the Creative Commons Attribution license (http://creativecommons.org/licenses/by/4.0/). 